\title{
Inclusion of discarded banana in sugarcane silage decreases dry matter losses and improves its nutritional value ${ }^{\text {a }}$
}

\author{
La inclusión de banano de descarte en el ensilaje de caña de azúcar reduce las pérdidas de materia seca y \\ mejora su valor nutricional
}

\section{A inclusão de banana de descarte em silagem de cana de açúcar decresce as perdas de matéria seca e melhora o seu valor nutricional}

Jaqueline da P S Rodrigues ${ }^{1}$, Zoot, MSc; Mário A Á Queiroz ${ }^{*}$, Zoot, DSc; Alita R F de Lucena ${ }^{2}$, MV, MSc; Fernanda S Costa $^{I}$, Zoot; Dalinne T Q de Carvalho ${ }^{I}$, Zoot, MSc; Mateus M da Costa $^{2}$, MV, DSc; Rafael T de S Rodrigues ${ }^{2}$, MV, DSc.

${ }^{1}$ Departamento de Ciência Animal, Universidade Federal do Vale do São Francisco, Petrolina, Pernambuco, 56300-990, Brasil.

${ }^{2}$ Departamento de Ciências Veterinárias no Semiárido, Universidade Federal do Vale do São Francisco, Petrolina, Pernambuco, 56300-990, Brasil.

(Received: July 18, 2017; accepted: April 13, 2018)

doi: 10.17533/udea.rccp.v32n1a06

\begin{abstract}
Background: Sugarcane silage (SCS) has often been characterized by large dry matter (DM) losses associated with reduction in soluble nutrients and increase in indigestible fiber. Objective: To evaluate the effect of including discarded fruits on the losses and nutritional value in SCS. Methods: A completely randomized design was used with five treatments and five replications. Silages were added with $15 \%$ (as-fed basis) papaya (Carica papaya) (SP), acerola (Malpighia glabra) (SA), banana (Musa sp.) (SB) or tomato (Solanum lycopersicum) (ST). The control treatment was composed only of SCS. Twenty-five (25-L) plastic buckets were used to make the experimental silos, which were opened on the 90th day after their closure. Data were analyzed by analysis of variance. Results: Gas losses and total DM losses were lower and DM recovery was higher in SB and SA than in the control $(\mathrm{p}<0.05)$. The SB had lower content of neutral detergent fiber and acid detergent fiber compared to SP, SA, ST and the control group $(\mathrm{p}<0.05)$. There was no effect of treatment for ethanol content $(\mathrm{p}>0.05)$. However, there was treatment effect for lactic and acetic acids, ammonia nitrogen contents, lactic acid bacteria, and yeasts and mold counts $(p<0.05)$. Conclusion: The inclusion of $15 \%$ banana or acerola in SCS decreases losses and increases DM recovery. Furthermore, the inclusion of $15 \%$ banana improves the nutritional value of SCS.
\end{abstract}

Keywords: additives, animal feeding, crop byproduct, fiber content, forage conservation, discard fruit.

a To cite this article: Rodrigues JdPS, Queiroz MAÁ, de Lucena ARF, Costa FS, de Carvalho DTQ, da Costa MM, Rodrigues RTdS. Inclusion of discarded banana in sugarcane silage decreases dry matter losses and improves its nutritional value. Rev Colomb Cienc Pecu 2019; 32(1):50-57.

* Corresponding Author: Mário Adriano Ávila Queiroz. Departamento de Ciência Animal, Universidade Federal do Vale do São Francisco, Petrolina, Pernambuco 56304-917, Brasil. Tel.: +55-87-21014845. E-mail: mario.queiroz@univasf.edu.br 


\section{Resumen}

Antecedentes: El ensilaje de caña de azúcar (SCS) es frecuentemente caracterizado por grandes pérdidas de materia seca (DM) asociadas con reducciones en los nutrientes solubles y aumentos en la fibra indigestible. Objetivo: Evaluar el efecto de la inclusión de frutas de descarte sobre las perdidas y el valor nutricional del SCS. Métodos: Se utilizó un diseño completamente aleatorizado con cinco tratamientos y cinco repeticiones. Fueron adicionados a los ensilajes, $15 \%$ (materia natural) de papaya (Carica papaya) (SP), acerola (Malpighia glabra) (SA), banano (Musa sp.) (SB) o tomate (Solanum lycopersicum) (ST). El control estuvo compuesto apenas por SCS. Veinticinco baldes de $25 \mathrm{~L}$ fueron usados para hacer los silos, los cuales se abrieron al día 90 posterior a su cierre. Los datos fueron analizados por análisis de varianza. Resultados: Las pérdidas de gases y de DM total fueron menores y la recuperación de DM fue mayor en SB y SA que en el grupo control $(\mathrm{p}<0,05)$. Los contenidos de fibra detergente neutra y ácida fueron menores en SB comparados con SP, SA, ST y el grupo control $(p<0,05)$. No hubo efecto para el contenido de etanol $(p>0,05)$. Sin embargo, hubo efecto de tratamiento para los contenidos de ácidos láctico y acético, y nitrógeno amoniacal y recuento de bacterias ácido lácticas, levaduras y hongos $(\mathrm{p}<0,05)$. Conclusiones: La inclusión de $15 \%$ de banano y acerola en SCS decreció las perdidas, y aumentó la recuperación de DM. Además, la inclusión de un 15\% de banano mejoró el valor nutricional de SCS.

Palabras clave: aditivos, alimentación animal, conservación de forraje, contenido de fibra, fruta de descarte, subproducto de cosecha.

\section{Resumo}

Antecedentes: A silagem de cana de açúcar (SCS) é frequentemente caracterizada por grandes perdas de matéria seca (DM) associadas com reduções nos nutrientes solúveis e aumento na fibra indigestível. Objetivo: Avaliar o efeito da inclusão de frutas de descarte sobre as perdas e o valor nutricional de SCS. Métodos: Um delineamento completamente casualizado foi utilizado, com cindo tratamentos e cinco repetições. As silagens foram adicionadas com 15\% (matéria natural) de mamão (Carica papaya) (SP), acerola (Malpighia glabra) (SA), banana (Musa sp.) (SB) ou tomate (Solanum lycopersicum) (ST). O controle foi composto apenas por SCS. Vinte e cinco baldes de $25 \mathrm{~L}$ foram usados para fazer os silos, que foram abertos no $90^{\circ}$ dia após o fechamento deles. Os dados foram analisados por meio de análise de variância. Resultados: As perdas por gases e de DM total foram menores e a recuperação de DM foi maior em SB e SA que no controle $(p<0,05)$. Os conteúdos de fibra em detergente neutro e ácido foram menores em SB comparado a SP, SA, ST e o grupo de controle $(p<0,05)$. Não houve efeito para conteúdo de etanol $(p>0,05)$. Contudo, houve efeito de tratamento para os conteúdos de ácidos lático e acético, e nitrogênio amoniacal e contagens de bactérias láticas, e leveduras e fungos ( $p<0,05)$. Conclusões: A inclusão de $15 \%$ de banana e acerola em SCS decresceu as perdas, e aumentou a recuperação de DM. Adicionalmente, a inclusão de 15\% de banana melhorou o valor nutricional da SCS.

Palavras-chave: aditivos, alimentação animal, conservação de foragem, conteúdo de fibra, subproduto da colheita, fruta descartada.

\section{Introduction}

Sugarcane is one of the main roughages produced in tropical and subtropical regions, mainly due to its high productivity. However, the daily harvesting and processing of sugarcane demand plenty of labor, which is very expensive. Thus, sugarcane has been widely used as silage for animal feed. Nevertheless, sugarcane silage has often been characterized by large dry matter (DM) losses associated with reduction of soluble nutrients and increased indigestible fiber (Pedroso et al., 2005; Oliveira et al., 2015).
Several studies have aimed to reduce losses and improve the nutritional value of sugarcane silage (Carvalho et al., 2012; Santos et al., 2015; Gandra et al., 2016). Absorbent additives, and agricultural by-products have been studies to improve the quality of silages with high DM content and soluble carbohydrates (Yitbarek and Tamir, 2014). The inclusion of detoxified castor bean meal and soybean crop residue decreased DM losses and neutral detergent fiber content in sugarcane silages (Freitas et al., 2006; Oliveira et al., 2015). 
Brazil is one of the largest fruit producers in the world (OECD-FAO, 2015). This high yield generates a large amount of discarded fruit, which can pollute the environment if not properly disposed. Therefore, discarded fruits could be used in sugarcane silage to reduce DM losses and improve its nutritional value. To the best of our knowledge, there are no studies on the use of discarded fruits in sugarcane silage. Thus, the aim of the current study was to evaluate the effect of inclusion of discarded fruits on losses and nutritional value of sugarcane silage.

\section{Materials and methods}

The study was conducted in the Laboratory of Animal Requirements and Metabolism, located at the Campus of Agricultural Sciences of Universidade Federal do Vale do São Francisco (UNIVASF), in Petrolina, Pernambuco, Brazil. Experimental silages were produced from sugarcane (variety RB 579) planted in Juazeiro, Bahia, Brazil. The sugarcane was cut fresh at approximately 18 months and chopped and ground in a forage crusher (TRF 400F, Trapp ${ }^{\circledR}$, Jaraguá do Sul, SC, Brazil) adjusted to 2 cm particle size.

Sugarcane silages were added with 15\% (as-fed basis) of papaya (Carica papaya) (SP), acerola (Malpighia glabra) (SA), banana (Musa sp.) (SB) or tomato (Solanum lycopersicum) (ST). The fruits used were over-ripe, at an initial stage of deterioration (discarded fruit). The control treatment was composed only of sugarcane silage. Urea was added to all treatments ( $1 \%$ on a DM basis) to increase the low crude protein $(\mathrm{CP})$ content of sugarcane silage.
Fruits were chopped in a forage crusher. The DM content was 9.2, 19.7, 10.2 and 3.4 for acerola, banana, papaya and tomato, respectively. Due to the low DM contents of fruits, they were sun-dried for $9 \mathrm{~h}$ in 1-cm layers before being added to the silages. The nutritional composition of sugarcane and dried fruits used for silage production are shown in Table 1.

Twenty-five (25 L) plastic buckets were used to make the experimental silos. Two kg of dry sand were placed at the bottom of each bucket to absorb leaching losses of the ensiled material, and a screen was placed on top of the sand to separate it from the silage. The silos were sealed with plastic lids and stored at room temperature $\left(25^{\circ} \mathrm{C}\right)$, protected from sunlight and rain. Silage density was calculated from the ensiled mass and silo volume. Approximately $3.4 \mathrm{~kg}$ of fresh matter were weighed in each silo.

The silos were opened on the 90th day after their closure. Gas losses were obtained by weight difference at the closing and opening of the silo relative to the DM weight of the ensiled material. Effluent losses were calculated as the difference between initial and final weight of the silos containing sand and screen in relation to the weight of the ensiled material. Losses and DM recovery were calculated from weights and DM contents of fresh forage and silage.

After opening, the contents of the silos were homogenized and samples were taken. Silage samples were analyzed for DM (method 934.01; AOAC, 1990), ash (method 924.05; AOAC, 1990), CP (method 920.87; AOAC, 1990), and ether extract (EE, method 920.85; AOAC 1990). Neutral detergent fiber (NDF) and acid detergent fiber (ADF) were

Table 1. Nutritional composition of sugarcane and dried discarded fruits used for silage.

\begin{tabular}{|c|c|c|c|c|c|}
\hline Variable & Sugarcane & Tomato & Banana & Acerola & Papaya \\
\hline Dry matter (DM; \%) & 32.0 & 7.1 & 34.6 & 11.3 & 22.2 \\
\hline Ash (\% DM) & 2.4 & 7.8 & 7.7 & 6.0 & 9.6 \\
\hline Neutral detergent fiber (\% DM) & 56.2 & 30.1 & 33.6 & 32.2 & 21.1 \\
\hline Acid detergent fiber (\% DM) & 38.8 & 28.2 & 18.5 & 29.5 & 19.1 \\
\hline Soluble carbohydrates (\% DM) & 21.5 & 3.6 & 13 & 3.5 & 7.1 \\
\hline
\end{tabular}


determined using the sequential method according to Van Soest et al. (1991). Acid detergent insoluble nitrogen (ADIN) and total nitrogen (TN) were analyzed according to Mertens (2002). Nonstructural carbohydrates (NSC) and total carbohydrates (TC) were calculated according to Sniffen et al. (1992). Water-soluble carbohydrates (WSC) were determined by the phenol-sulfuric acid method (Dubois et al., 1956). Total digestible nutrients (TDN) were estimated as follows (Harlan et al., 1991):

$$
\mathrm{TDN}=82.75-(0.704 * \mathrm{ADF})
$$

Fresh silage samples were pressed with a $15-\mathrm{t}$ hydraulic press to obtain the silage extract used to measure $\mathrm{pH}$, ethanol and organic acids. The $\mathrm{pH}$ was determined using a digital potentiometer (Digimed Analytical, São Paulo, SP, Brazil). The concentrations of lactic, acetic, propionic and butyric acids, and ethanol were measured by gas chromatography using a chromatograph (Thermo Scientific, Sunnyvale, CA, USA) fitted with a flame ionization detector and automatic sample injection.

An aqueous extract was prepared for microbiological analyzes. A sample of $25 \mathrm{~g}$ of fresh sugarcane silage was blended in $225 \mathrm{~mL}$ of $0.1 \%$ sterile peptone water and homogenized in an orbital shaker for $20 \mathrm{~min}$. Identification and quantification of the different microbial groups were performed according to Jobim et al. (2007).

A completely randomized design was used with five treatments and five replications. The ST treatment had four replicates because one of the silos was lost. Data were analyzed by analysis of variance using the
SAS $^{\circledR}$ (Statistic Analysis System) software, version 9.1 (SAS Institute, Cary, NC, USA, 2003). The statistical model used was as follows:

$$
Y=\mu+\alpha+e
$$

Where:

$\mu$ : is the overall mean.

$\alpha:$ is the effect of treatment.

$e:$ is the random error.

The Tukey's test at $5 \%$ of probability was used to compare means between treatments.

\section{Results}

The values of losses, $\mathrm{pH}$ and silage density are shown in Table 2. Although effluent losses were numerically lower in sugarcane silages enriched with discarded fruits compared to control, there were no significant differences $(p>0.05)$ between treatments. However, gas losses and total DM losses were lower in SB and SA than in the control $(p<0.05)$. The ST and SP treatments did not differ from the control for gas losses and total DM losses ( $p>0.05$ ). In addition, SB and SA had greater DM recovery compared to SP, ST and the control $(\mathrm{p}<0.05)$. The ST and SP treatments did not differ from the control for DM recovery $(p>0.05)$. The highest and lowest silage density was obtained in SB and SP, respectively $(p<0.05)$. The SA, ST and control had intermediate values and did not differ $(p>0.05)$ between them. The $\mathrm{pH}$ of SB did not differ $(\mathrm{p}>0.05)$ from that of ST, but it was higher $(p<0.05)$ than those obtained in the control, SA and SP treatments.

\begin{tabular}{|c|c|c|c|c|c|c|}
\hline Variable & Control & ST & SB & SA & SP & SEM \\
\hline Density $\left(\mathrm{kg}\right.$ fresh matter $\left.(\mathrm{FM}) / \mathrm{cm}^{3}\right)$ & $510.0^{b c}$ & $513.2^{b}$ & $556.7^{a}$ & $515.8^{b}$ & $498.2^{c}$ & 4.43 \\
\hline $\mathrm{pH}$ & $3.51^{b}$ & $3.57^{a b}$ & $3.64^{a}$ & $3.52^{b}$ & $3.51^{b}$ & 0.01 \\
\hline Effluent losses (kg/ton FM) & $45.3^{a}$ & $29.6^{a}$ & $27.3^{a}$ & $31.6^{a}$ & $28.5^{a}$ & 2.63 \\
\hline Gas losses (\% dry matter; DM) & $23.4^{a}$ & $22.5^{a}$ & $13.2^{b}$ & $15.2^{b}$ & $28.4^{a}$ & 1.40 \\
\hline Total DM losses (\%) & $27.0^{a}$ & $24.9^{a}$ & $15.7^{b}$ & $18.0^{b}$ & $30.6^{a}$ & 1.37 \\
\hline DM recovery (\%) & $72.0^{b}$ & $75.0^{b}$ & $82.9^{a}$ & $81.9^{a}$ & $69.3^{b}$ & 1.37 \\
\hline
\end{tabular}

Table 2. Effect of inclusion of $15 \%$ discarded fruits (as-fed basis) on the density, $\mathrm{pH}$ and losses of sugarcane silage

Control = sugarcane; ST = sugarcane + tomato; SB = sugarcane + banana; SA = sugarcane + acerola; SP = sugarcane + papaya. SEM = standard error of the mean. Means followed by different superscript letters $\left({ }^{a}, b, c\right)$ within the same row differ statistically $(p<0.05)$ by the Tukey's test. 
Nutritional value of silages is shown in Table 3. Control and SB resulted in the highest DM contents, while SP had the lowest $(\mathrm{p}<0.05)$. Silages enriched with discarded fruits had higher ash contents compared to the control $(\mathrm{p}<0.05)$. The CP and EE contents were not affected by treatments $(p>0.05)$. On the other hand, the fiber content was affected $(p<0.05)$. The SB had lower content of NDF and ADF compared to SP, SA, ST and the control. The highest and lowest NSC contents were obtained in SB and ST, respectively $(p<0.05)$. The ADIN and ADIN:TN ratio were higher in $\mathrm{SB}, \mathrm{SA}$ and $\mathrm{SP}$ compared to the control and ST $(p<0.05)$. The SB had highest TDN content $(\mathrm{p}<0.05)$.

The count of lactic acid bacteria (LAB), molds, yeasts, and final fermentation product contents of the silages are shown in Table 4 . The SP had higher LAB count than the control $(\mathrm{p}<0.05)$. The SB, SA and ST did not differ from the control for LAB count $(p>0.05)$. The SP had the lowest count of yeasts and molds, while the SB had the highest $(\mathrm{p}<0.05)$. The SA, ST and control had intermediate values. There was no effect of treatment for ethanol, soluble carbohydrate, propionic and butyric acids contents $(p>0.05)$. However, the contents of lactic acid, acetic acid, and ammonia nitrogen were affected $(\mathrm{p}<0.05)$. Lactic acid was higher in ST and SA compared to SP, SB and the control, which did not differ between them. Acetic acid was higher in the SA compared to SP, SB, ST and control, which did not differ between them. The SP had higher ammonia nitrogen than the control. However, there were no differences between the control and ST, SB or SA for ammonium nitrogen.

Table 3. Effect of $15 \%$ inclusion of discarded fruits (as-fed basis) on the nutritional composition of sugarcane silage.

\begin{tabular}{|c|c|c|c|c|c|c|}
\hline Variable & Control & ST & SB & SA & SP & SEM \\
\hline Dry matter (DM; \%) & $26.8^{a}$ & $25.3^{a b}$ & $26.6^{a}$ & $24.9^{a b}$ & $23.8^{b}$ & 0.19 \\
\hline Ash (\% DM) & $2.4^{b}$ & $5.2^{a}$ & $6.2^{a}$ & $5.4^{a}$ & $5.5^{a}$ & 0.33 \\
\hline Crude protein (\% DM) & $11.8^{a}$ & $12.5^{a}$ & $12.7^{a}$ & $12.4^{a}$ & $11.5^{a}$ & 0.19 \\
\hline Ether extract (\% DM) & $0.85^{a}$ & $1.08^{a}$ & $1.57^{a}$ & $1.40^{a}$ & $1.72^{a}$ & 0.13 \\
\hline Neutral detergent fiber (\% DM) & $65.7^{a}$ & $66.9^{a}$ & $59.4^{b}$ & $65.1^{a}$ & $64.7^{a}$ & 0.65 \\
\hline Acid detergent fiber (\% DM) & $44.3^{a}$ & $45.8^{a}$ & $38.5^{b}$ & $43.6^{a}$ & $43.3^{a}$ & 0.58 \\
\hline Nonstructural carbohydrates (\% DM) & $15.1^{a b}$ & $13.4^{b}$ & $20.0^{a}$ & $15.5^{a b}$ & $15.2^{a b}$ & 0.67 \\
\hline Soluble carbohydrates (\% DM) & $1.18^{a}$ & $1.22^{a}$ & $1.50^{a}$ & $1.25^{a}$ & $1.17^{a}$ & 0.04 \\
\hline Total carbohydrates (\% DM) & $80.9^{a}$ & $80.3^{a}$ & $79.4^{a}$ & $80.6^{a}$ & $79.9^{a}$ & 0.65 \\
\hline Acid detergent insoluble nitrogen (ADIN) (\% DM) & $0.29^{b}$ & $0.34^{b}$ & $0.49^{a}$ & $0.47^{a}$ & $0.45^{a}$ & 0.01 \\
\hline ADIN/Total nitrogen (\%) & $0.14^{b}$ & $0.16^{b}$ & $0.24^{a}$ & $0.24^{a}$ & $0.23^{a}$ & 0.01 \\
\hline Total digestible nutrients (\%) & $51.3^{b}$ & $50.4^{b}$ & $56.2^{a}$ & $51.6^{b}$ & $52.0^{b}$ & 0.44 \\
\hline
\end{tabular}

Control = sugarcane; ST = sugarcane + tomato; SB = sugarcane + banana; SA = sugarcane + acerola; SP = sugarcane + papaya. SEM = standard error of the mean. Means followed by different superscript letters $\left({ }^{a, b}\right)$ within the same row differ statistically $(p<0.05)$ by the Tukey's test.

Table 4. Effect of inclusion of $15 \%$ discarded fruits (as-fed basis) in sugarcane silage on microbial count and concentration of fermentation products.

\begin{tabular}{|c|c|c|c|c|c|c|}
\hline Variable & Control & ST & SB & SA & SP & SEM \\
\hline Lactic acid bacteria (log cfu/g) & $3.04^{b}$ & $3.17^{a b}$ & $3.10^{b}$ & $3.04^{b}$ & $3.26^{a}$ & 0.02 \\
\hline Yeasts and molds (log cfu/g) & $2.27^{c}$ & $2.43^{c}$ & $3.74^{a}$ & $2.92^{b}$ & $1.79^{d}$ & 0.09 \\
\hline Ethanol (\% dry matter; DM) & $10.7^{a}$ & $9.3^{a}$ & $8.2^{a}$ & $9.0^{a}$ & $8.4^{a}$ & 0.31 \\
\hline Lactic acid (\% DM) & $2.1^{b}$ & $3.4^{a}$ & $2.3^{b}$ & $3.5^{a}$ & $2.5^{b}$ & 0.13 \\
\hline Acetic acid (\% DM) & $1.5^{b}$ & $2.0^{b}$ & $1.5^{b}$ & $3.4^{a}$ & $1.4^{b}$ & 0.17 \\
\hline Propionic acid (\% DM) & $0.11^{a}$ & $0.12^{a}$ & $0.14^{a}$ & $0.14^{a}$ & $0.13^{a}$ & 0.01 \\
\hline Butyric acid (\% DM) & $0.05^{a}$ & $0.05^{a}$ & $0.06^{a}$ & $0.05^{a}$ & $0.05^{a}$ & 0.00 \\
\hline Ammonia nitrogen (\% DM) & $8.9^{b}$ & $10.8^{a b}$ & $10.5^{a b}$ & $9.9^{a b}$ & $12.1^{a}$ & 0.31 \\
\hline
\end{tabular}

Control = sugarcane; ST = sugarcane + tomato; SB = sugarcane + banana; SA = sugarcane + acerola; SP = sugarcane + papaya. SEM = standard error of the mean. Means followed by different letters letters $(a, b, c, d)$ within the same row differ statistically $(p<0.05)$ by the Tukey's test. 


\section{Discussion}

Sugarcane silage without additives is characterized by high DM losses (Freitas et al., 2006; Oliveira et al., 2015). Thus, several researchers have evaluated additives in sugarcane silages (Carvalho et al., 2012; Santos et al., 2015). In our study, the use of discarded banana and acerola decreased gas and total DM losses of sugarcane silage, which could explain the higher DM recovery in SB and SA. The DM losses in sugarcane silage have been related mainly to the degradation of its high soluble carbohydrate content by yeasts, which are naturally abundant in sugarcane (Carvalho et al., 2014). In addition to its high substrate content, the rapid growth of yeasts in sugarcane silage has been attributed to its low DM content (Andrade $e t$ al., 2001; Oliveira et al., 2015). However, it is unlikely that the beneficial effect of adding banana and acerola on losses and DM recovery in sugarcane silage was due to increased DM content, because the sugarcane silage in our study had high DM content (32\%) at the time of ensiling, which could be considered within the ideal range for producing good quality silage. In addition, the DM content of acerola was much lower $(11.3 \%)$ than that of sugarcane. Thus, other factors such as presence of secondary compounds in banana and acerola (Ehiowemwenguan et al., 2014; Marques et al., 2016) might inhibit or regulate the activity of microorganisms responsible for undesirable fermentation in sugarcane silage. Similar effect was not observed with addition of tomato and papaya, since ST and SP did not differ from control for gas losses, total DM losses, and DM recovery.

A high content of pectin in banana peel (up to $21.7 \%$ DM) could also cause lower DM losses in SB (Emaga et al., 2008). Pectin, as starch and sugars, has high fermentation capacity, but its fermentation is mainly acetic ( $85 \%$ short chain fatty acids) (Ítavo et al., 2000). Acetic acid inhibits yeast and mold growth (Muck, 2010), which could help reduce ensiling losses. However, pectin content was not estimated in our study. Studies using the non-sequential method for NDF and ADF analysis could be used to estimate pectin content in fruits. Nevertheless, acetic acid content was not high in SB, and it had a greater number of yeast and mold, indicating that other mechanisms could be involved in low DM losses. Moreover, the high density of SB could also be related to its low total DM losses. On the other hand, the low density observed in the control and SP could be linked to their high gas and total DM losses. High silage density is related to low oxygen content within the silo, which contributes to decrease losses from undesirable fermentation (Muck, 1988).

Although SB had the lowest total DM losses, it had the highest $\mathrm{pH}$ value, indicating that $\mathrm{pH}$ per se is not indicative of good quality silage, and other parameters should be also considered. Nevertheless, the $\mathrm{pH}$ values obtained in all treatments were lower than the maximum limit (4.2) established to characterize good quality silage (Woolford, 1984).

The low DM content in SP could be related to its high gas and total DM losses, and low DM recovery. The high ash content in discarded fruits could explain the high ash present in silages with inclusion of fruits compared to the control.

Interestingly, although banana had higher NDF content than the other fruits, SB had lower NDF concentration. This result could be due to the low total DM loss in SB, because DM losses in sugarcane silage is related to soluble nutrients losses, increasing the concentration of insoluble nutrients (Pedroso et al., 2005; Oliveira et al., 2015). This effect was not observed in SA that also had lower DM loss than the control, ST and SP. Although the content of NDF was similar between banana and acerola, the hemicellulose:NDF ratio was $45 \%$ in banana, and $8 \%$ in acerola, confirming that banana fiber is more soluble than acerola.

The SB also had the lowest ADF content. The low DM loss in SB would more likely explain this result than the low ADF content in banana, as SP had higher ADF than SB, although papaya and banana had similar ADF. The low ADF could explain the high TDN content in SB.

Therefore, in addition to reducing silage DM losses, inclusion of discarded banana in the silage may decrease its fiber content, which could increase sugarcane silage digestibility, because the high fiber content related to large losses of soluble nutrients is considered a limiting factor for the use of sugarcane silage in ruminant feed (Jacovaci et al., 2017). 
The large DM losses in sugarcane silage have been attributed mainly to the high naturally-occurring yeast growth in sugarcane, which generates ethanol from fermentation of soluble carbohydrates (Carvalho et al., 2012; Carvalho et al., 2014). However, SB had high yeast and mold count, and low DM loss. Despite this, ethanol content did not differ between treatments. This result should be considered with caution, because the technique used did not allow for the separate quantification of molds and yeasts. In addition, the high yeasts content at the time of silo opening is not always indicative of low quality silage (Carvalho et al., 2015). However, as ethanol content did not differ between treatments, significant differences in yeast population might not have occurred.

The lack of difference in ethanol content between the control and fruit-added treatments could be related to the inclusion of urea in all treatments, as urea can be converted to ammonia during silage fermentation, which in turn may inhibit yeasts (Kung Jr. et al., 2000).

The high lactic acid and acetic acid concentration in SA could help explain the low loss and high DM recovery in SA, because the high content of these organic acids may inhibit growth of undesirable microorganisms in silage (Danner et al., 2003; Dunière et al., 2013). Inoculation of acetic acidproducing bacteria has been reported to reduce effluent production, yeast count and ethanol concentration in sugarcane silage (Pedroso et al., 2008).

Although SP had higher LAB count, it had higher loss and lower DM recovery, indicating that this parameter per se is not a good indicator of silage quality, as LAB can reduce acetate concentration, which has antifungal effects, as previously discussed. In addition, LAB may increase lactate concentration in silage, which is a substrate for yeast growth (Weinberg et al., 1993). Furthermore, inoculation of sugarcane silage with LAB has been associated with low DM recovery, which could be related to excessive fermentation due to its high soluble carbohydrates content (Oliveira et al., 2017).

Ammonia nitrogen was relatively high in all treatments. This may be related to the addition of urea prior to ensiling, which can be easily converted to ammonia. In addition, it is unlikely that it is linked to excessive protein degradation by undesirable bacteria (e.g., Clostridium), because butyric acid, another important end product of undesirable bacterial fermentation, was low in all treatments. Despite this, ammonia nitrogen values in all treatments were lower than the $12 \%$ limit used to classify good quality silage (McDonald et al., 1991).

We conclude that $15 \%$ inclusion of banana or acerola in sugarcane silage reduces losses and increases dry matter recovery. In addition, 15\% banana inclusion decreases fiber content and increases nonstructural carbohydrates of sugarcane silage. However, $15 \%$ inclusion of tomato or papaya does not reduce dry matter losses nor improves the nutritional quality of sugarcane silage.

\section{Acknowledgements}

The authors are grateful to Conselho Nacional de Desenvolvimento Científico e Tecnológico (CNPq, Brazil) and Coordenação de Aperfeiçoamento de Pessoal de Nível Superior (CAPES, Brazil) for financial support. The authors wish to thank MSc. Germán Darío Ramírez Zamudio for his help in translating the abstract to Spanish.

\section{Conflicts of interest}

The authors declare they have no conflicts of interest with regard to the work presented in this report.

\section{References}

Andrade JB, Ferrari Júnior E, Braun G. Valor nutritivo da silagem de cana-de-açúcar tratada com uréia e acrescida de rolão-de-milho. Pesq Agropec Bras 2001; 36:1169-1174.

AOAC. Official method of analysis. 15th ed. Arlington, VA: Association of official analytical chemists; 1990.

Carvalho BF, Ávila CLS, Pinto JC, Pereira MN, Schwan RF. Effects of propionic acid and Lactobacillus buchneri (UFLA SIL 72) addition on fermentative and microbiological characteristics of sugar cane silage treated with and without calcium oxide. Grass Forage Sci 2012; 67:462-471.

Carvalho BF, Ávila CLS, Pinto JC, Neri J, Schwan RF. Microbiological and chemical profile of sugar cane silage fermentation inoculated with wild strains of lactic acid bacteria. Anim Feed Sci Tech 2014; 195:1-13. 
Carvalho BF, Ávila CLS, Miguel MGCP, Pinto JC, Santos MC, Schwan RF. Aerobic stability of sugar-cane silage inoculated with tropical strains of lactic acid bacteria. Grass Forage Sci 2015; 70:308-323.

Danner H, Holzer M, Mayrhuber E, Braun R. Acetic acid increases stability of silage under aerobic conditions. Appl Environ Microbiol 2003; 69:562-567.

Dubois M, Gilles KA, Hamilton JK, Rebers PT, Smith F. Colorimetric method for determination of sugars and related substances. Anal Chem 1956; 28:350-356.

Dunière L, Sindou J, Chaucheyras-Durand F, Chevallier I, Thévenot-Sergentet D. Silage processing and strategies to prevent persistence of undesirable microorganisms. Anim Feed Sci Tech 2013; 182:1-15.

Ehiowemwenguan G, Emoghene AO, Inetianbor JE. Antibacterial and phytochemical analysis of Banana fruit peel. IOSR J Pharm 2014; 4:18-25.

Emaga TH, Robert C, Ronkart SN, Wathelet B, Paquot M. Dietary fibre components and pectin chemical features of peels during ripening in banana and plantain varieties. Bioresour Technol 2008; 99:4346-4354.

Freitas AWP, Pereira JC, Rocha FC, Costa MG, Leonel FP, Ribeiro MD. Avaliação da qualidade nutricional da silagem de cana-deaçúcar com aditivos microbianos e enriquecida com resíduo da colheita de soja. R Bras Zootec 2006; 35:38-47.

Gandra JR, Oliveira ER, Takiya CS, et al. Chitosan improves the chemical composition, microbiological quality, and aerobic stability of sugarcane silage. Anim Feed Sci Tech 2016; 214:44-52.

Harlan DW, Holter JB, Hayes HH. Detergent fiber traits to predict productive energy of forages fed free choice to nonlactating dairy cattle1. J Dairy Sci 1991; 74:1337-1353.

Ítavo LCV, Santos GT, Jobim CC, Voltolini TV, Ferreira CCB. Substituição da silagem de milho pela silagem do bagaço de laranja na alimentação de vacas leiteiras. Consumo, produção e qualidade do leite. Rev Bras Zootec 2000; 29:1498-1503.

Jacovaci FA, Jobim CC, Schmidt P, Nussio LG, Daniel JLP. A data-analysis on the conservation and nutritive value of sugarcane silage treated with calcium oxide. Anim Feed Sci Tech 2017; 225:1-7.

Jobim CC, Nussio LG, Reis RA, Schmidt P. Avanços metodológicos na avaliação da qualidade da forragem conservada. R Bras Zootec 2007; 36:101-119.

Kung Jr L, Robinson JR, Ranjit NK, Chen JH., Golt CM, Pesek JD. Microbial populations, fermentation end-products, and aerobic stability of corn silage treated with ammonia or a propionic acidbased preservative1. J Dairy Sci 2000; 83:1479-1486.

Marques TR, Caetano AA, Alves DS, Ramos VO, Simão AA, Carvalho GA, Correa AD. Malpighia emarginata DC. bagasse acetone extract: Phenolic compounds and their effect on Spodoptera frugiperda (JE Smith) (Lepidoptera: Noctuidae). Chil J Agric Res 2016; 76:55-61.
McDonald P, Henderson AR, Heron SJE. Biochemistry of Silage, 2nd ed. Marlow: Chalcombe Publications; 1991.

Mertens DR. Gravimetric determination of amylase-treated neutral detergent fiber in feeds with refluxing in beaker or crucibles: collaborative study. J AOAC Int 2002; 85:1217-1240.

Muck RE. Factors influencing silage quality and their implications for management1. J Dairy Sci 1988; 71:2992-3002.

Muck RE. Silage microbiology and its control through additives. R Bras Zootec 2010; 39:183-191.

OECD-FAO Agricultural Outlook 2015. Brazilian agriculture: Prospects and challenges. OECD-FAO, 2015. DOI: 10.1787/ agr_outlook-2015-en.

Oliveira AC, Garcia R, Pires AJV, Oliveira, HC, Almeida VVS, SILVA RR, Nascimento Filho CS, Abreu Filho G. Chemical composition and fermentation characteristics of sugar cane silage enriched with detoxified castor bean meal. Arq Bras Med Vet Zoo 2015; 67:181-188.

Oliveira AS, Weinberg ZG, Ogunade IM, Cervantes AAP, Arriola KG, Jiang Y, Kim D, Li X, Gonçalves MCM, Vyas D. Meta-analysis of effects of inoculation with homofermentative and facultative heterofermentative lactic acid bacteria on silage fermentation, aerobic stability, and the performance of dairy cows. J Dairy Sci 2017; 100:4587-4603.

Pedroso AF, Nussio LG, Paziani SF, Loures DRS, Igarasi MS, Coelho RM, Packer IH, Horii J, Gomes LH. Fermentation and epiphytic microflora dynamics in sugar cane silage. Sci Agric 2005; 62:427-432.

Pedroso AF, Nussio LG, Loures DRS, Paziani SF, Ribeiro JL, Mari LJ, Zopollatto M, Schmidt P, Mattos WRS, Horii J. Fermentation, losses, and aerobic stability of sugarcane silages treated with chemical or bacterial additives. Sci. Agric. 2008; 65:589-594.

Santos WP, Carvalho BF, Ávila CLS, Dias Júnior GS, Pereira $\mathrm{MN}$, Schwan RF. Glycerin as an additive for sugarcane silage. Ann Microbiol 2015; 65:1547-1556.

SAS $^{\circledR}$, Statistical Analysis System. SAS/STAT User's guide: Statistics. Version 9.1. Cary, NC: SAS Inst. Inc.; 2003.

Sniffen CJ, O'connor JD, Van Soest PJ, Fox DG, Russell JB. A net carbohydrate and protein system for evaluating cattle diets: II. Carbohydrate and protein availability. J Anim Sci 1992; 70:3562-77.

Van Soest PV, Robertson JB, Lewis BA. Methods for dietary fiber, neutral detergent fiber, and nonstarch polysaccharides in relation to animal nutrition. J Dairy Sci 1991; 74:3583-97.

Weinberg ZG, Ashbell G, Hen Y, Azrieli A. The effect of applying lactic acid bacteria at ensiling on the aerobic stability of silages. J Appl Bacteriol 1993; 75:512-8.

Woolford MK. The silage fermentation. New York, NY: Marcel Dekker; 1984.

Yitbarek MB, Tamir B. Silage additives: review. Open J Appl Sci 2014; 4:258-74. 